\title{
The impact of brand concept on brand equity
}

\author{
Joo-Eon Jeon \\ Department of Business Administration, Anyang University, \\ Anyang, South Korea
}

\begin{abstract}
Purpose - Researches on the impact brand equity have grown considerably in recent years, as it has been shown to have significant impact on a company's financial performance. This paper aims to empirically test the relationships between brand concepts and brand equity, while exploring the mediating roles of emotional attachment and customer commitment.

Design/methodology/approach - The research investigates the effect of brand concept on the customer-brand relationship and brand performance. Additionally, it examines how the relationship between brand concept and brand equity is mediated by customer-brand relationships such as emotional attachment and commitment.

Findings - The results empirically demonstrate the important contribution of the three brand concepts to brand equity. The results empirically demonstrate the important contribution of the three-brand concept to customer commitment and to brand equity that has been predicted by prior research.

Originality/value - The main contribution of this study is to demonstrate the effects of the brand concepts related to aesthetic, functional and symbolic benefits on brand equity. From this, brand equity may be viewed as a link in the path of effects that indirectly connects brand concepts with market performance. Brand concept, emotional attachment and customer commitment are relevant constructs underlying brand equity, and commitment and loyalty are key mediating variables in relational exchanges.
\end{abstract}

Keywords Brand concept, Commitment, Brand equity, Emotional attachment

Paper type Research paper

\section{Introduction}

The importance of brand equity has been recognized in the marketing literature for at least three decades as an intangible asset that promotes firm performance. Brand equity has been shown to make an impact on brand loyalty and the financial value of the company (Chaudhuri and Holbrook, 2001; Oliver, 1999; Srivastava et al., 1998). Research on brand equity has evaluated the importance of the brand in marketing strategy and has sparked managerial interest. Brand equity has also been defined in a number of different ways for different purposes and has been addressed using comparative methods, holistic methods and the interplay between branding and financial considerations.

Aaker (1991) has discussed the role of customer commitment in brand equity management and has specifically noted that strong commitment leads to competitive advantages such as reduced marketing costs and attracting new customers. An important

(C) Joo-Eon Jeon. Published in the Asia Pacific Journal of Innovation and Entrepreneurship. Published by Emerald Publishing Limited. This article is published under the Creative Commons Attribution (CC BY 4.0) licence. Anyone may reproduce, distribute, translate and create derivative works of this article (for both commercial and non-commercial purposes), subject to full attribution to the original publication and authors. The full terms of this licence may be seen at http://creativecommons.org/ licences/by/4.0/legalcode
Impact of brand concept

Received 20 November 2016 Revised 14 January 2017 13 February 2017 Accepted 14 February 2017

Acc

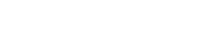

e 
determinant of a customer commitment is a brand manager's abilities to select a brand concept (Chaudhuri and Holbrook, 2001; Park et al., 1986). A brand concept is selected brand image derived from consumer needs (Park et al., 1986) and is the culmination of a diverse array of direct and indirect brand equity features such as brand awareness and brand identity. That is, brand management is a process of selecting a concept. Prior researchers have assigned products to one of three categories on the basis of product class: functional (e.g. massagers), symbolic (e.g. watches) or aesthetic (e.g. artwork). A product may be a physical good like an automobile, a watch or a pencil, or it can be a service like a bank, a hotel or an airline. This research, however, uses the terms functional, symbolic and aesthetic to refer to the benefit created in a brand, not as a product class (Malär et al., 2011; Park et al., 1986). The brand benefit is a perception created by marketers' management of the brand. As a result, author expects that this brand concept is an antecedent of strong brand relationship.

Recently, increasing interest among brand manager has focused on strong brand relationships because they reflect customer loyalty through emotional attachment, and commitment (Fournier, 1998; Morgan and Hunt, 1994; Oliver, 1999). Commitment represents professed faithfulness and loyalty to the brand (Fournier, 1998). Emotional attachment is affinity towards the brand, with respect to other available alternatives. Emotional bonds may range from feelings of warmth to true passion (Thomson et al., 2005). Marketing managers are able to justify expenditures on promotions that have the potential to generate such long-term consumer effects as emotional attachment and customer commitment (Brakus et al., 2009; Chaudhuri and Holbrook, 2001; Malär et al., 2011). Furthering understanding of the process of developing the brand relationship and the notion of brand equity will benefit from an empirically supported explanation for these crucial brand concepts.

The purpose of this research is to present a path model that would provide useful structure for managers developing brand concept management and researchers studying brand equity. To define the brand concept construct, this paper begins with a review of marketing research, which examines when brand concepts and how they affect attachment, commitment and brand equity. The present study explores the relationships between emotional attachment, commitment and brand equity with an emphasis on understanding the linking role played by brand concept. To develop hypotheses, the authors draw from the new and emerging concepts of customer-brand relationship and brand equity. These conceptualizations are crucial aspects of an integrated process of brand fortification and brand performance. The author then presents the methods, measures and results of surveys designed to test the hypotheses of interest. Finally, the study concludes with a discussion of the results in terms of their managerial relevance and implications for future research.

\section{Theoretical background}

Previous research has determined that a brand is a name, term, sign, symbol, design or signalling combination that is intended to identify the goods and services of one seller or group of sellers (Aaker, 1991; Kotler and Armstrong, 2010). As a concept, branding has been around for decades as a means to distinguish the goods of a particular producer. Park et al. (1986) have suggested that the long-term success of a brand depends on selecting a brand concept prior to market entry. These authors define brand concept in terms of firm-selected brand meaning derived from consumer needs. Specially, a brand concept consists of an aesthetic, functional and symbolic brand (Park et al., 2013), which represent distinct constructs. 
The aesthetic brands are designed to fulfil consumer's needs for sensory pleasure (Jeon and Lee, 2016). "Aesthetics" comes from the Greek word aesthesis, referring to sensory perception and understanding (Krishna et al., 2010; Kumar and Garg, 2010). In the eighteenth century, the philosopher Baumgarten picked up the term and changed its meaning into gratification of the senses delight (Goldman, 2001). Aesthetic experiences are becoming increasingly relevant to the marketing due to growing importance of experiential aspects of consumption (Hirschman and Holbrook, 1982). Aesthetic appeal and design have been of interest to human beings and have captured their imagination throughout history (Patrick and Hagtvedt, 2011; Krishna et al., 2010). Aesthetic experiences can have a deeprooted influence on consumer affect, cognition and behaviour. In a marketing context, aesthetic needs are defined as desires for products that provide aesthetic pleasure. When consumers take product quality for granted, aesthetics becomes an important criterion (Park et al., 1986; Park et al., 2013) in the purchasing decision. Aesthetics have been investigated in the visual sense, but other senses, for example, taste, smell and the interaction of senses, do constitute aesthetic experiences in traditional marketing research (Krishna et al., 2010). The full form of appreciation of an aesthetic experience comes from the combination of sensory input (Kumar and Garg, 2010).

The functional brands should emphasize the functional performance. Prior research has defined functional value as the ability to perform functions in the everyday life of a consumer (Hirschman and Holbrook, 1982). Functional needs are defined as those that motivate the search for products that solve consumption-related problems (Park et al., 1986; Park et al., 2013). These needs are linked to basic motivations and are met by products with functional performance. Therefore, a functional brand is designed to solve externally generated consumption needs (Chaudhuri and Holbrook, 2001; Brakus et al., 2009). Park et al. (2010) indicate that brands can be managed to reduce uncertainty in consumers' lives and enable the attainment of desired outcomes by facilitating control and efficacy. Hence, functional brands are related to product performance. Brands with visual representations of functional benefits are capable of reminding customers of the brand's functionality and/or communicating such benefits to them (Keller, 1993).

The symbolic brands should emphasize the relationship between brand and selfidentification. These brands can reflect a part of consumer's identities. Park et al. (2013) defined self-expressiveness brand as the brand with symbolic concept. Brands have the ability to help express or define customers' actual or desired selves and to differentiate customers' selves from those of others (McCracken, 1990). Brands also become relevant to customers by connecting the individual to others who share similar values and beliefs. Symbolic needs are defined as desires for products that fulfil internally generated needs for self-enhancement, social role or ego-identification (Holbrook and Hirschman, 1982). A symbolic brand benefit is one that is designed to associate the individual with a desired group, role or self-image (Park et al., 1986). Consumers may value the prestige, exclusivity or fashionability of a brand because it relates positively to their self-concept. A symbolic brand can be a critical tool for conveying associations between the brand and the self, which in turn helps the consumer see the brand as part of themselves (Hirschman and Holbrook, 1982). Brands with symbolic benefits have the potential to not only express brand-self associations but also to reinforce and strengthen them, thus enhancing customers' willingness to exert effort and invest resources towards sustaining their relationship with the brand (McCracken, 1990; Park et al., 2010).

This research proposes that the aesthetic, functional and symbolic brands are each related to both emotional attachment and commitment. This proposition stems from the emerging theory of brand commitment in relationship marketing (Fournier, 1998; Morgan 
APJIE 11,2

and Hunt, 1994). In the context of maintaining brand relationships, the emotional determinants of brand commitment need to be considered separately. Brand commitment leads to greater market performance when the same brand is repeatedly purchased by consumers, irrespective of situational constraints (Fournier, 1998). Research has also shown that superior brand performance outcomes such as greater market share may result from greater customer commitment (Park et al., 2010). This commitment, in turn, may be determined by clear brand concept. Therefore, the initial goal of this research is to clearly conceptualize these constructs and suggest the path of each construct towards the overall brand conceptualization.

\section{Hypotheses development}

\subsection{Aesthetic brand concept and sensory experience}

For brands with aesthetic benefits, brand strategies should convey the brand's effect on sensory satisfaction. Using the brand should highlight the aesthetic aspects associated with consumption. Brands with aesthetic benefit are designed to fulfil internally generated needs for aesthetic pleasure (Park et al., 1986) and are more likely to build connections with their customers than are brands with low aesthetic qualities (Goldman, 2001). Thus, the aesthetic benefit of brand is an important component of a brand's ability to appeal to customers and has the potential to emotionally connect with them, thereby enhancing their brand loyalty.

According to prior research, sensory experience is fundamental to the formation of aesthetic stimuli (Brakus et al., 2009; Hirschman and Holbrook, 1982). Therefore, the sensory experience is an important platform for enabling the brand to differentiate itself and create an opportunity for intense consumer relationships (Patrick and Hagtvedt, 2011). The positive impact of the brand with aesthetic benefit will affect sensory experience. Based on this theoretical background, the following hypothesis is proposed:

H1. Brands with aesthetic benefits are positively related to sensory experience.

\subsection{Functional brand concept and customer commitment}

This research expects brands that convey functional benefits will encourage customers to rely on the brand as a solution for consumption-related problems, thereby enhancing customers' brand commitment. As a result, functional brands may have the potential to communicate and reinforce a brand's promise to assist customers in their daily lives and, in so doing, can strengthen customers' relationships with the brand (Morgan and Hunt, 1994; Park et al., 2013). Satisfaction with functional brands appears to serve as a key determinant of customer commitment, consistent with the concept of brand management (Fournier, 1998).

Commitment has been defined as an enduring desire to maintain a customer-brand relationship (Moorman et al., 1992). Fournier (1998) suggested that commitment represents a high-quality brand relationship. Thus, customer commitment underlies a continued valuable relationship that has been created by customer satisfaction. In a marketing context, consumers with commitment intend to continue a long-term relationship and have a willingness to remain in the relationship (Chaudhuri and Holbrook, 2001; Oliver, 1999). Consumers who are satisfied with functional brands are committed to preserving the relationship with the brand. Therefore, satisfaction with a functional brand and consumer commitment should be related, as satisfaction is important in the relational exchange (Oliver, 1999).

The information-processing paradigm regards consumer behaviour as largely objective and rational when oriented towards problem solving (Moorman et al., 1992; Chaudhuri and Holbrook, 2001). Thus, customer trust in a particular favoured functional brand may be greater 
when the utilitarian value in the product category is high in terms of tangible product attributes, such as quality or convenience. Furthermore, Chaudhuri and Holbrook (2001) found that the functional value of brand was significantly and negatively related to emotional response. Based on this theoretical background, the following hypothesis is proposed:

H2. Brands with functional benefits are positively related to commitment.

\subsection{Symbolic brand concept and emotional attachment}

This research proposes that brands with symbolic benefits are related to both sensory experiences and emotional attachment. This proposition stems from the emerging theory of brand commitment in relationship marketing (Fournier, 1998). Park et al. (2010) defines brand attachment as the strength of the bond connecting the brand with the self. This bond is exemplified by a rich and accessible memory network that involves thoughts and feelings about the brand and the brand's relationship to the self (Thomson et al., 2005). Consumers can be connected to a brand because it represents who they are or because it is meaningful in light of goals, personal concerns, or life projects (McCracken, 1990). The idea that attachment involves an emotional bond suggests that a critical aspect of attachment involves the connection between the brand and the self, defined here and elsewhere as brand-self connection (Escalas, 2004a, 2004b).

Brand-self connection is a core component of attachment because it reflects the definition of attachment as the bond connecting a person with the brand (Thomson et al., 2005). In this study, emotional attachment is defined as a brand's potential to elicit a positive emotional response in the average consumer as a result of its use (Thomson et al., 2005). Attachment is increasingly viewed in terms of the aesthetic elements of brand symbolism and cultural significance, and the emotions and resonance that these produce in the hearts and minds of consumers (Malär et al., 2011). Furthermore, previous research proposes that a valid measure of emotional attachment should predict consumer's commitment to a brand and their loyalty to that brand (Thomson et al., 2005). Overall, consumers' emotional attachment to a brand leads to their commitment to the relationship with that particular brand. Therefore, this research proposes the following hypothesis:

H3. Brands with symbolic benefits are positively related to both sensory experiences and emotional attachment.

\subsection{Customer commitment and brand equity}

In a general sense, brand equity is defined in terms of the marketing effects that are uniquely attributable to the brand (Aaker, 1991; Keller, 1993; Kotler and Armstrong, 2010). For example, brand equity is evident when certain outcomes that result from the marketing of a product or service due to its brand name would not occur if the product or service did not possess the name (Kotler and Armstrong, 2010). A number of factors influence a company's brand equity, including the firm's strategic insights and how effectively the firm implements its chosen strategy. However, one of the key drivers of brand equity is customers' commitment to the firm's brand (Srivastava et al., 1998). The extent to which customers are loyal to a firm's brand influences the stability and growth of the firm's revenues and profits over time, serving to protect the firm from competitive threats (Srivastava et al., 1998).

Customer commitment can be viewed as an enduring desire to maintain a valued relationship with the brand (Chaudhuri and Holbrook, 2001; Park et al., 2013). Consumers having strong levels of commitment, who have nurtured strong relationships with the brand, 
APJIE 11,2

tend to see strong connections between themselves and the brand (Escalas and Bettman, 2003) and consider the brand to be an integral part of their lives. In this study, the authors argue that committed consumers are likely to view brand changes as threatening to their relationship with the brand. This research also proposes that high consumer commitment to a brand is linked through brand equity to greater market share and premium prices in the marketplace. Based on this theoretical background, the following hypothesis is proposed:

H4. Customer commitment is positively related to brand equity.

\section{Methodology}

This study aims to show that brand benefits can explain the relationship between brand concept and brand performance. The research investigates the effect of brand concept on the customer-brand relationship and brand performance. Additionally, it examines how the relationship between brand concept and brand equity is mediated by customer-brand relationships such as emotional attachment and commitment.

\subsection{Stimuli}

For the stimuli used in this study, the authors drew a random sample of 100 brands from the Interbrand Group published listing. All data are available through The Best Global Brands List. The sample was representative of The Best Global Brands as a whole, as the selected brands do not differ from the remaining firms on any critical financial measure. The Best Global Brands of Interbrand Group factors in many criteria when ranking the world's most valuable brands such as Apple, Coco-cola, Google and Samsung. The focus of this research is on overall brands rather than individual products, as no data are available for examining the relationship between brands and firm performance at the product level. After selecting the brands, the authors secured official brand logos from the company's websites.

\subsection{Sample and data collection procedure}

The authors obtained the sample for this study by recruiting adult survey participants from Amazon's Mechanical Turk. Four hundred and sixty participants (47.2 per cent male, $\mathrm{M}_{\mathrm{age}}=$ 38.8) completed the survey, for which they received US\$0.50. Based on random assignment, each participant evaluated different brands in a questionnaire. The questionnaire included one brand logo on each page, followed by the set of items shown in Table I. Each brand logo in the sample received roughly the same number of survey responses.

\subsection{Measures}

The items in each measure were assessed on a seven-point Likert scale, where $1=$ strongly disagree and $7=$ strongly agree (see Appendix). To measure brand concept, the authors adapted six items from the scale by Park et al. (2013). The authors measured sensory experience using three items modelled after Brakus et al. (2009). To measure emotional attachment, the study included a version of the scale that consists of the attachment dimension: affection, passion and connection (Malär et al., 2011). Finally, to measure commitment, the authors adopted three items from the recent work by Park et al. (2013).

For the examination of brand equity, it was important to select a forward-looking and cumulative measure that is comparable across a variety of brands in different industries. In this regard, The Best Global Brands 2015 List of Interbrand Group has received wide acceptance in the current marketing literature as an appropriate measure of brand equity. Its methodology evaluates brands much the same way that analysts value other assets: on the 
Scale

Aesthetic benefit

Aesthetic benefit 1

Aesthetic benefit 2

Functional benefit

Functional benefit 1

Functional benefit 2

Symbolic benefit

Symbolic benefit 1

Symbolic benefit 2

Sensory experience

Sensory experience 1

Sensory experience 2

Sensory experience 3

Emotional attachment

Emotional attachment 1

Emotional attachment 2

Emotional attachment 3

Commitment

Commitment 1

Commitment 2

Commitment 3

Factor loadings Composite reliability Average variance extracted Mean (S.D)

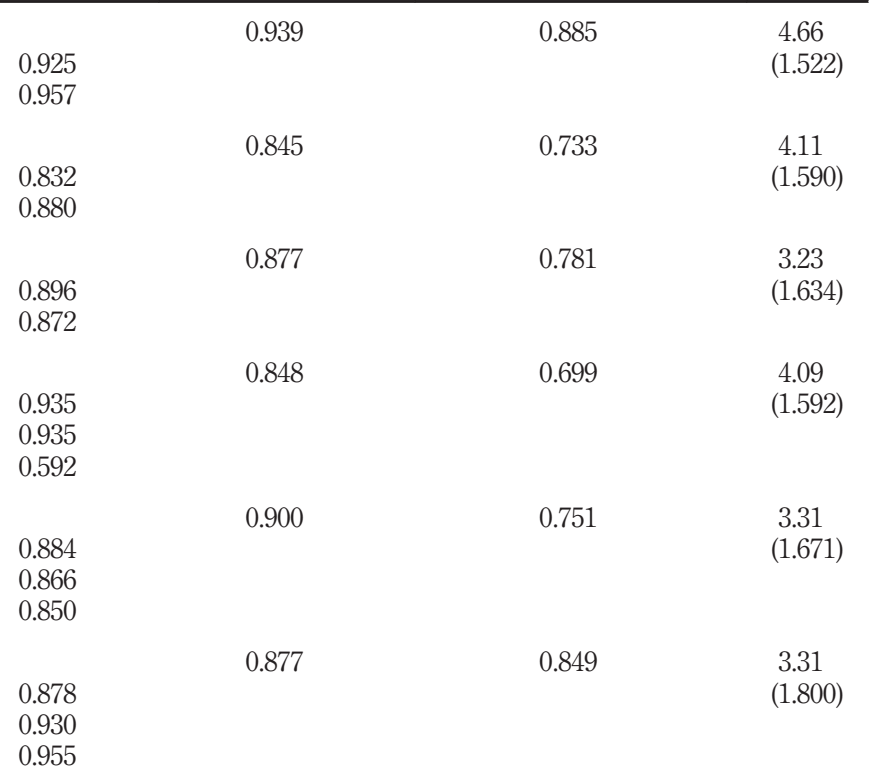
brand concept (and 239

Notes: $X^{2}=204.207(p=0.000, \mathrm{df}=75)$ RMSEA $=0.061 ; \mathrm{NFI}=0.969 ; \mathrm{CFI}=0.980 ;$ TLI $=0.972$; RR $=$ Statistics of construct 0.091 items

basis of how much they are likely to earn in the future. Interbrand Group has used a subjective multiplier of brand profits based on the brand' performance along seven dimensions: leadership, stability, market stability, internationality, trend, support and protection.

\section{Results}

\subsection{Data analysis}

The reliability of the measurement items was first tested for internal consistency. The scales were evaluated to be reliable, showing a satisfactory reliability level of Cronbach's $\alpha$ at above 0.7 , which is a generally accepted level: aesthetic benefit $=0.939$; functional benefit $=$ 0.845 ; symbolic benefit $=0.877$; sensory experience $=0.848$; emotional attachment $=0.900$; commitment $=0.941$. Next, the authors confirmed convergent validity and discriminant validity of the measurement through a confirmatory factor analysis (CFA). Table I shows the overall results from the CFA. Model fit was found to be significant since all of the model fit indicators were acceptable: root mean square error of approximation (RMSEA) $=0.057$; normed fit index $(\mathrm{NFI})=0.966$, comparative fit index $(\mathrm{CFI})=0.979$; Turker-Lewis index $(\mathrm{TLI})=0.972$; goodness of fit index $(\mathrm{GFI})=0.938$ with $\chi^{2}=224.042, p<0.001$ (ratio between chi-square and the number of degrees of freedom $=89$ ). Table II shows the correlations between constructs.

Figure 1 shows the overall results of hypotheses tests. Solid lines indicate a significant relationship, whereas dotted lines indicate a non-significant relationship of the data. As the 
APJIE 11,2

\section{0}

Table II.

Correlation between constructs (AVE and squared correlations) authors predicted, the results empirically demonstrate a positive relationship between the three-brand concept and customer commitment and brand equity. The structural equation modelling results show that the brand concepts have a positive and significant impact on customer commitment, which in turn positively influences brand equity.

\subsection{Brand concepts and the customer-brand relationship}

$H 1$ proposes that when consumers perceive brands to have aesthetic appeal, they are more likely to have a sensory experience. The path between aesthetic brands and sensory experience was significant (0.404), whereas the path between aesthetic brands and emotional attachment was not significant. Additionally, sensory experience is significantly related to emotional attachment (0.428). These results reveal a significant, indirect influence of the aesthetic benefits on emotional attachment, indicating that sensory experience acts as a partial mediator in brands with aesthetic benefit-emotional attachment. These results

\begin{tabular}{lllllll}
\hline Construct & AES & FUN & SYM & SEN & EMO & COM \\
\hline AES & $0.783^{*}$ & & & & & \\
FUN & 0.516 & $0.537^{*}$ & & & & \\
SYM & 0.599 & 0.648 & $0.609^{*}$ & & & \\
SEN & 0.684 & 0.557 & 0.654 & $0.488^{*}$ & & \\
EMO & 0.540 & 0.568 & 0.714 & 0.669 & $0.564^{*}$ & \\
COM & 0.535 & 0.601 & 0.698 & 0.637 & 0.785 & $0.720^{*}$
\end{tabular}

Notes: *The numbers on the diagonal are the square roots of the average variance extracted; AES, aesthetic benefit; FUN, functional benefit; SYM, symbolic benefit; SEN, sensory experience; EMO, emotional attachment; COM, commitment

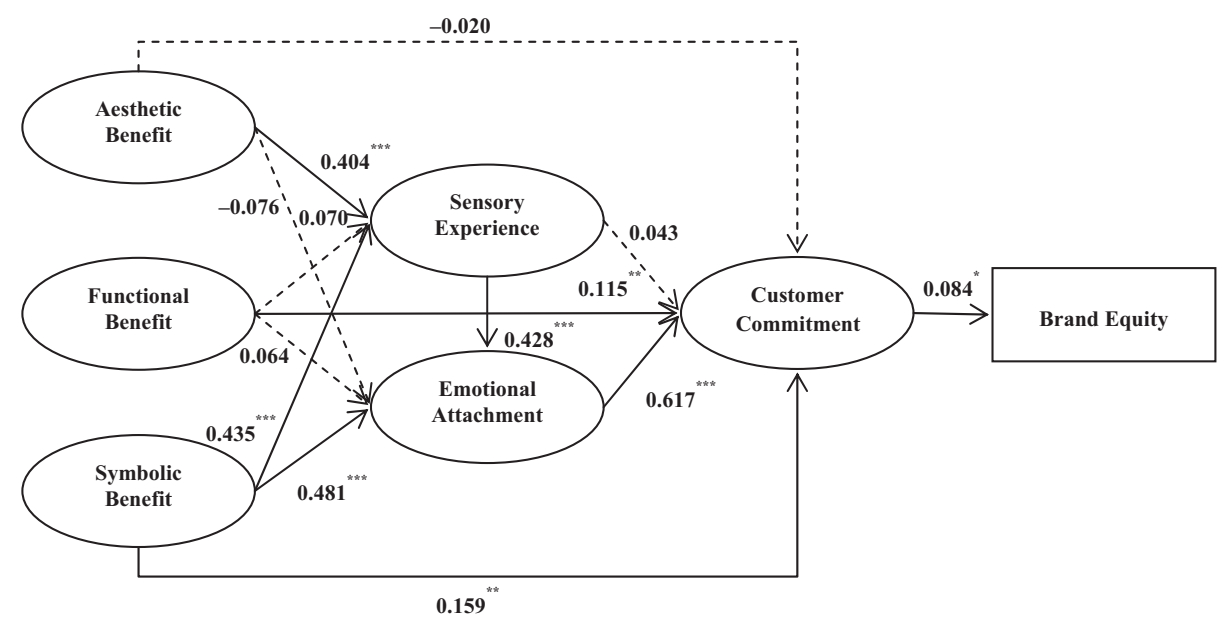

Figure 1.

Hypotheses testing
Notes: $X^{2}=224.042(p=0.000, \mathrm{df}=89)$;MSEA $=0.057$;FI $=0.966 ; \mathrm{CFI}=0.979 ; \mathrm{TLI}=$ $0.972 ; \mathrm{GFI}=0.938 ; * p<0.80 ; * *<0.05 ; * * * p<0.01$ 
support the hypothesis that brands with aesthetic appeal can be associated with sensory experience.

As this research predicted, brands with functional benefits affect commitment $(H 2)$. The direct effect of functional brands on commitment is significant (0.115), whereas the effect on both sensory experience and emotional attachment is not significant. That is, functional brand seems to be a stronger predictor of actual commitment than emotional attachment. The functional benefit serves as a basic and fundamental descriptor of product category. This result reveals that brands with functional benefits have an impact on commitment, as functional brand objectives are rational and oriented toward problem solving.

Finally, the authors predicted that brands with symbolic benefits would be positively related to both sensory experiences and emotional attachment. The path between symbolic brand and sensory experience is significant (0.435) as is the path between symbolic brand and emotional attachment (0.481). Therefore, symbolic brands affect sensory experience and emotional attachment. Brands with symbolic benefits can express a significant part of the self-concept. Thus, this result reveals that consumers who satisfied with symbolic brands are more likely to be connected to a brand. The overall results of this study demonstrate that the aesthetic, functional and symbolic benefits of brand are all positively related to customer commitment.

\subsection{Customer commitment and brand equity}

There are differential effects of sensory experience and emotional attachment on customer commitment. The direct effect of emotional attachment on commitment (0.617) is significant. However, the direct effect of sensory experience on commitment is not significant. Thus, emotional attachment seems to be a stronger predictor of customer commitment than sensory experience. This result may be related to the nature of relationship marketing where sensory experiences are viewed not as objective entities but as subjective symbols (Hirschman and Holbrook, 1982). Multisensory experiences have never actually occurred, but are experienced as mental phenomena. Thus, sensory experiences can be combined into an emotional attachment. If a brand stimulates emotional bonds, then consumers seeking a connection may be motivated to strive for such strong relationship again. As a result, emotional attachment is an antecedent of customer commitment.

Finally, the results reveal a significant, direct influence of customer commitment on brand equity (0.084). The path empirically demonstrates the important contribution of the brand benefit to commitment and to brand equity. This result reveals that the one of the important determinants of brand equity is the commitment to a particular brand. As a result, the results suggest that if customers are loyal to a brand, then a firm's brand can achieve stability and growth of brand-related revenue.

\section{Discussion}

The important findings from this research are as follows: First, this study found that emotional attachment was positively and significantly affected by brand benefit including aesthetic and symbolic brand concepts. Second, this study found that consumers' emotional attachment has a positive influence on customer commitment. This result strongly supports the notion that emotional attachment and commitment are distinct constructs, which confirms the results of previous research (Malär et al., 2011; Park et al., 2010; Thomson et al., 2005). Finally, this research suggests that customer commitment affects brand equity significantly. These findings suggest that aesthetic, functional and symbolic brands are separate constructs that combine to determine different types of emotional attachment and commitment related aspects of brand equity. 
APJIE 11,2
This conceptualization has been corroborated by our empirical results, in which different outcomes were evident for brand concepts as opposed to brand performance. Functional brand was related to customer commitment, and this was indirectly related brand equity, whereas aesthetic and symbolic brand concepts contributed to both sensory experience and emotional attachment, which in turn contributed significantly to brand equity. From this, it follows that brand equity may be viewed as a link in the path of effects that indirectly connects brand concepts with the market performance aspects of brand equity. Brand concept, emotional attachment and customer commitment are relevant constructs in determining brand equity, which considers commitment or loyalty to be key mediating variables in relational exchanges (Morgan and Hunt, 1994). As contributors to brand concept, emotional attachment and commitment have distinct antecedents.

The results of this research indicate that marketing managers need to consider brands as powerful tools in brand management, more so than previously thought. More specifically, just because consumers can quickly identify a brand based on its characteristics does not mean that they will invest resources towards sustaining their relationship with that brand. Brand characteristics that are easily recognizable, yet which do not convey the brand's symbolic and functional benefits or do not provide aesthetic gratification, fail to take full advantage of their full potential.

Marketing managers can interpret these results to help justify expenditures on brand strategies that create such long-term relationships with consumers by enhancing emotional attachment and commitment, as these consumer-level constructs contribute to profitable brand equity. Communicating brand positioning to a target consumer has been regarded as an important marketing strategy. Consumers need to feel good about the brand concept and have positive emotional experiences and connections to the brand. A well-communicated brand position should enhance its market performance.

Based on these results, managers may develop differentiated brand concept strategies and tactics. The authors suggest that brand concept in terms of firm manager-selected positioning derived from target consumers' needs. Thus, managers have the management plan consist of a sequential process of selecting, introducing and elaborating brand concept. Ultimately, the top manager's goal in managing brand equity is to create a strong relationship between consumer and brand. In simple terms, if manager can build a customer commitment. This will result in the strong brand equity. This brand equity means higher customer retention rates for the manager as well as reduced marketing cost. The result is increased marketing profitability.

Presently, marketplace is very complex, and brands must be positioned particularly clearly. This study demonstrates that focusing on the brand management provides marketers with a valuable, largely untapped tool in their efforts to deepen customer-brand relationships and enhance brand equity.

Despite its meaningful findings, this study has some limitations. First, this study does not investigate the moderating role of other possible influential variables such as brandschematicity. Puligadda et al. (2012) suggested that brand-schematic consumers organize and interpret brand information at the level of the brand. Therefore, they have easy access to brand information in their memories. A brand-schematic consumer should pay more attention to brand information than a brand-aschematic consumer (Keller, 1993). Therefore, they are more like to evaluate a particular brand better, unless brand-schematicity is controlled. Future research could examine the moderating role of brand-schematicity. Second, it would be interesting to investigate the effect of consistency between brand concept and product category on a brands' evaluation. Brand concept taps brand-related information, while product category refers to product attribute information. It is possible 
that in an evaluation of a brand that inconsistency between brand concept and product category results in a lower evaluation of the customer-brand relationship. Finally, author does not distinguish between corporate and product brands, which can interact with commitment and impact brand equity. Future research could explore how corporate and product brands influence brand equity over time.

Note

1. Assistant Professor, Department of Business Administration, Anyang University, 22 Samdeok-ro 37beon-gil, Manan-gu, Anayang-si, Gyeonggi-Do, Korea. Tel: +82-10-8863-8533, E-mail: eric@ anyang.ac.kr

\section{References}

Aaker, D.A. (1991), Managing Brand Equity; Capitalizing on the Value of a Brand, The Free Press, New York, NY.

Brakus, J.J., Schmitt, B.H. and Zarantonello, L. (2009), "Brand experience: what is it? How is it measured? Does it affect loyalty?”, Journal of Marketing, Vol. 73 No. 3, pp. 52-68.

Chaudhuri, A. and Holbrook, M.B. (2001), "The chain of effects from brand trust and brand affect to brand performance: the role of brand loyalty", Journal of Marketing, Vol. 65 No. 2, pp. 81-93.

Escalas, J.E. (2004a), "Imagine yourself in the product: mental simulation, narrative transportation, and persuasion”, Journal of Advertising, Vol. 33 No. 2, pp. 37-48.

Escalas, J.E. (2004b), "Narrative processing: building consumer connections to brands", Journal of Consumer Psychology, Vol. 14 No. 1, pp. 168-179.

Escalas, J.E. and Bettman, J.R. (2003), "You are what they eat: the influence of reference groups on consumers' connections to brands", Journal of Consumer Psychology, Vol. 13 No. 3, pp. 339-348.

Fournier, S. (1998), "Consumers and their brands: developing relationship theory in consumer research", Journal of Consumer Research, Vol. 24 No. 4, pp. 343-353.

Goldman, A. (2001), "The aesthetic", in Gaut, B.N. and Lopes, D. (Eds), The Routledge Companion to Aesthetics, Routledge, London.

Hirschman, E.C. and Holbrook, M.B. (1982), "Hedonic consumption: emerging concepts, methods and propositions", Journal of Marketing, Vol. 46 No. 3, pp. 92-101.

Holbrook, M.B. and Hirschman, E.C. (1982), “The experiential aspects of consumption: consumer fantasies, feelings, and fun", Journal of Consumer Research, Vol. 9 No. 2, pp. 132-140.

Jeon, J.E. and Lee, J. (2016), "Brand schematicity moderates the effect of aesthetic brands on brand accessories purchase intentions", Social Behavior and Personality, Vol. 44 No. 10, pp. 1733-1746.

Keller, K.L. (1993), “Conceptualizing, measuring, and managing customer-based brand equity”, Journal of Marketing, Vol. 57 No. 1, pp. 1-22.

Kotler, P. and Armstrong, G. (2010), Principles of Marketing, Pearson Education, Upper Saddle River, NJ.

Krishna, A., Elder, R. and Caldara, C. (2010), "Feminine to smell but masculine to touch? Multisensory congruence and its effect on the aesthetic experience", Journal of Consumer Psychology, Vol. 21 No. 3, pp. 410-418.

Kumar, M. and Garg, N. (2010), "Aesthetic principles and cognitive emotion appraisals: how much of the beauty lies in the eye of the beholder?", Journal of Consumer Psychology, Vol. 20 No. 4, pp. 485-494.

McCracken, G.D. (1990), Culture and Consumption: New Approaches to the Symbolic Character of Consumer Goods and Activities, Indiana University Press, Bloomington. 
APJIE 11,2

Malär, L., Krohmer, H., Hoyer, W.D. and Nyffenegger, B. (2011), "Emotional brand attachment and brand personality: the relative importance of the actual and the ideal self", Journal of Marketing, Vol. 75 No. 4, pp. 35-52.

Moorman, C., Zaltman, G. and Deshpande, R. (1992), "Relationships between providers and users of market research: the dynamics of trust within and between organizations", Journal of Marketing Research, Vol. 29 No. 3, pp. 314-328.

Morgan, R.M. and Hunt, S.D. (1994), “The commitment-trust theory of relationship marketing”, Journal of Marketing, Vol. 58 No. 3, pp. 20-38.

Oliver, R.L. (1999), “Whence consumer loyalty?”, Journal of Marketing, Vol. 63 No. 4, pp. 33-44.

Park, C.W., Eisingerich, A.B., Pol, G. and Park, J.W. (2013), "The role of brand logos in firm performance", Journal of Business Research, Vol. 66 No. 2, pp. 180-187.

Park, C.W., Jaworski, B.J. and Maclnnis, D.J. (1986), "Strategic brand concept-image management", Journal of Marketing, Vol. 50 No. 4, pp. 135-145.

Park, C.W., MacInnis, D.J., Priester, J., Eisingerich, A.B. and Iacobucci, D. (2010), "Brand attachment and brand attitude strength: conceptual and empirical differentiation of two critical brand equity drivers", Journal of Marketing, Vol. 74 No. 6, pp. 1-17.

Patrick, V.M. and Hagtvedt, H. (2011), “Aesthetic incongruity resolution”, Journal of Marketing Research, Vol. 48 No. 2, pp. 393-402.

Puligadda, S., Ross, W.T. Jr. and Grewal, R. (2012), "Individual differences in brand schematicity", Journal of Marketing Research, Vol. 49 No. 1, pp. 115-130.

Srivastava, R.K., Shervani, T.A. and Fahey, L. (1998), "Market-based assets and shareholder value: a framework for analysis", Journal of Marketing, Vol. 62 No. 1, pp. 2-18.

Thomson, M., MacInnis, D.J. and Park, C.W. (2005), "The ties that bind: measuring the strength of consumers' emotional attachments to brands", Journal of Consumer Psychology, Vol. 15 No. 1, pp. $77-91$. 
Appendix

\begin{tabular}{|c|c|c|c|}
\hline Constructs & Scale items & Sources & \\
\hline Aesthetic benefit & $\begin{array}{l}\text { [Brand name]'s logo is aesthetically (visually) pleasing to } \\
\text { me } \\
\text { [Brand name]'s logo provides aesthetic pleasure to me }\end{array}$ & Park et al. (2013) & 245 \\
\hline Functional benefit & $\begin{array}{l}\text { [Brand name]'s logo represents the functional benefits I can } \\
\text { expect from the brand } \\
\text { [Brand name]'s logo ensures me that the brand assists me } \\
\text { in handling my daily life competently }\end{array}$ & & \\
\hline Symbolic benefit & $\begin{array}{l}\text { [Brand name]'s logo makes me think that [brand name] } \\
\text { expresses who I am as a person } \\
\text { [Brand name]'s logo makes me think that [brand name] } \\
\text { makes my life richer and more meaningful }\end{array}$ & & \\
\hline Sensory experience & $\begin{array}{l}\text { This brand makes a strong impression on my visual sense } \\
\text { or other senses } \\
\text { I find this brand interesting in a sensory way } \\
\text { This brand does not appeal to my senses }\end{array}$ & Brakus et al. (2009) & \\
\hline $\begin{array}{l}\text { Emotional } \\
\text { attachment }\end{array}$ & $\begin{array}{l}\text { My feelings toward the brand can be characterized by } \\
\text { affection } \\
\text { My feelings toward the brand can be characterized by } \\
\text { passion } \\
\text { My feelings toward the brand can be characterized by } \\
\text { connection }\end{array}$ & Malär et al. (2011) & \\
\hline Commitment & $\begin{array}{l}\text { I feel loyal towards [brand name] } \\
\text { Even if [brand name] would be more difficult to buy, I } \\
\text { would still keep buying it } \\
\text { I am willing to go the extra mile to remain a customer of } \\
\text { [brand name] }\end{array}$ & Park et al. (2013) & $\begin{array}{l}\text { Table AI. } \\
\text { Construct items }\end{array}$ \\
\hline
\end{tabular}

\section{Corresponding author}

Joo-Eon Jeon can be contacted at: eric@anyang.ac.kr

For instructions on how to order reprints of this article, please visit our website: 